\title{
Hepatitis C virus prevalence in Belgium
}

\author{
Luk Van Baelen* (D) and Johan Van der Heyden \\ Department of Epidemiology and public health, Sciensano, Brussels, Belgium \\ *Corresponding author. Email: luk.vanbaelen@sciensano.be
}

(Received 17 June 2021; Revised 07 September 2021; Accepted 07 September 2021)

\begin{abstract}
Reliable hepatitis C prevalence estimates are crucial for a good follow-up of the indicators to eliminate hepatitis by 2030 as set by the World Health Organization. In Belgium, no recent national population-based hepatitis $\mathrm{C}$ virus (HCV) seroprevalence estimate is available. The current study estimated HCV prevalence as part of the first Belgian Health Examination Survey, which was organized in 2018 as a second stage of the sixth Belgian Health Interview Survey. This national population-based cross-sectional study resulted in a weighted national HCV seroprevalence of $0.02 \%$ (95\% CI $0.00-0.07 \%$ ). The results show a much lower HCV seroprevalence compared to previous studies.
\end{abstract}

Keywords: Hepatitis C; seroprevalence; cross-sectional study; population estimate; Belgium

\section{Introduction}

The estimation of the prevalence of the hepatitis $\mathrm{C}$ virus $(\mathrm{HCV})$ in the general population is considered one of the 10 core indicators in the evaluation plan of the World Health Organization (WHO) to eliminate hepatitis by 2030 (World Health Organization, 2016). WHO defines HCV prevalence as the number and proportion of people living with a chronic HCV infection (HCV RNA positive or HCV antigen positive). In Belgium, the existing data on $\mathrm{HCV}$ prevalence focus on specific subpopulations (Van Baelen et al., 2020), are outdated (Beutels et al., 1997), limited to specific geographic areas (Beutels et al., 1997), or not representative because of the sampling method (Litzroth et al., 2019). In 2019, a metaanalysis of HCV prevalence studies performed between 2013 and 2019 estimated the HCV seroprevalence at $1.01 \%$ (95\% CI $0.64-1.42 \%)$ and the viremic prevalence at $0.33 \%$ (95\% CI $0.21-0.47 \%$ ) (Muyldermans et al., 2019). In the European Union/European Economic Area (EU/EEA), anti-HCV prevalence in the general population is estimated at $1.1 \%$ (95\% CI $0.9-1.4$ ), ranging from $0.1 \%$ in Belgium, Ireland, and the Netherlands to 5.9\% in Italy (Hofstraat et al., 2017).

\section{Methods}

The current HCV estimation was part of the first Belgian Health Examination Survey (BELHES), which was organized as a second stage of the sixth Belgian Health Interview Survey (BHIS). The BHIS was a cross-sectional epidemiological study in 2018 focusing on the health status, health behavior, and health consumption of the general Belgian population (Demarest et al., 2013). The sampling frame consisted of all households listed in the National Registry and was selected through a multistage stratified sampling (Demarest et al., 2013). Participants to the BHIS were invited to participate also in the BELHES. The study design of the BELHES is described more in detail elsewhere (Nguyen et al., 2020) and follows largely the technical protocol for hepatitis $\mathrm{C}$ prevalence surveys in the general population, as developed by the

\footnotetext{
(c) The Author(s), 2021. Published by Cambridge University Press. This is an Open Access article, distributed under the terms of the Creative Commons Attribution licence (http://creativecommons.org/licenses/by/4.0), which permits unrestricted re-use, distribution and reproduction, provided the original article is properly cited.
} 
European Centre for Disease Prevention and Control (2020). In short, the BELHES was open to all persons who participated in the BHIS except for minors ( $<18$ years), BHIS participants for whom a proxy interview was conducted, and residents of the German Community. Due to limited resources, the BELHES sample was initially limited to 1,100 respondents. As for the anti-HCV estimate, this was considered to be large enough: with a power of $80 \%$, an expected chronic $\mathrm{HCV}$ prevalence of $1.01 \%$ (Muyldermans et al., 2019) and a lower alternative prevalence of $0.1 \%$ (Hofstraat et al., 2017), a design effect of 1.3 and a $95 \%$ confidence level, a sample of 779 would have been sufficient (European Centre for Disease Prevention and Control, 2020). Recruitment stopped when regional quota was reached (Nguyen et al., 2020). Apart from a short face-to-face interview and a clinical examination, also blood and urine samples were collected. Exclusion criteria for blood samples included pregnancy, clotting disorders, the use of anticoagulant medicines, and a history of epileptic fits. Depending on the consent to have blood stored in a biobank or not, five or seven blood samples were taken from each respondent. Due to budgetary constraints, some analyses could not immediately be done after collection and samples were temporarily frozen at $-80^{\circ} \mathrm{C}$. This was the case for the analysis of HCV-antibodies which was done 10 months after the end of the fieldwork. Results were linked to the data from the BHIS and the BELHES questionnaire to determine risk factors of a positive HCV test result, such as country of birth and history of drug use (Nguyen et al., 2020). For key variables such as sociodemographic data, BELHES participants were compared to the other BHIS participants as well as to the general population. We applied survey weights to all results, taking into account the multistage stratified survey design, and will further report only weighted percentages, with corresponding 95\% CIs if relevant. Data analysis was done using Statistical Analysis System software version 9.4 (SAS Institute Inc., Cary, NC).

The presence of HCV-antibodies was determined using an HCV quantitative nucleic acid test on the frozen blood sample, based on a proprietary dual-probe assay design (cobas; Roche Diagnostics, Basel, Switzerland). Respondents with a positive result were tested again on a fresh whole blood sample. In case of a confirmation of the positive result, an HCV RNA test through a polymerase chain reaction (PCR) (Xpert HCV Viral Load with GeneXpert; Cepheid AB, Solna, Sweden) was done.

\section{Results}

The BELHES sample consisted of 1,184 participants, which corresponds to a participation rate of $24.1 \%$ of those who were eligible in the BHIS sample and who were contacted for participation (Nguyen et al., 2020). For 170 BELHES participants (14.4\%) blood collection was not possible due to selective refusal and difficulty in finding a vein. The remaining 1,014 respondents were tested for $\mathrm{HCV}$-antibodies. As shown in Table 1, participants who were tested for HCV were mainly female (50.5\%), on average of 49.4 years old, $28.3 \%$ had ever used cannabis, and 9.3\% had ever used other drugs ( $0.1 \%$ heroin, $6.7 \%$ cocaine, $0.2 \%$ crack, and 3.5\% amphetamines).

Moreover, $90.3 \%$ had a Belgian nationality, $15.7 \%$ were not born in Belgium, and $3.3 \%$ were born in a country with HCV prevalence figures above 2\% (Gower et al., 2014). Based on national data for 2018 from the Belgian Statistical Office (Belgian Statistical Institute, n.d.), people born in a country with HCV prevalence figures above $2 \%$ represent $3.2 \%$ of the Belgian population. For certain countries with a high HCV prevalence such as Gabon, Georgia, or Uzbekistan, there is only a small number of people in Belgium. The only country with high endemic HCV which was underrepresented in the study was Egypt, with only one participant in the BHIS, who did not participate in the BELHES.

BELHES respondents were higher educated than the BHIS respondents (51.9 vs. $47.0 \%$ had finished higher education), they were more living in Flanders (59.2 vs. 56.0\%), they were less living in rural areas (9.9 vs. $11.3 \%)$.

Out of 1,014 samples, only two samples tested anti-HCV positive, of which one sample turned out to be false positive after the confirmation test. The other anti-HCV positive case was a woman, aged 55 years old, without known risk profile regarding drug use or migration status. Her subsequent new blood sample did not have detectable HCV RNA. Taking into account survey design settings the one positive case that 
Table 1. Descriptive statistics of BHIS and BELHES samples ( $\geq 18$ years), weighted and unweighted percentages, and comparison with the Belgian population where possible (Belgian Statistical Institute, n.d.)

\begin{tabular}{|c|c|c|c|c|c|c|}
\hline & & \multicolumn{2}{|c|}{ BHIS } & \multicolumn{2}{|c|}{ BELHES } & \multirow[b]{2}{*}{$\begin{array}{c}\text { Belgian } \\
\text { population (\%) }\end{array}$} \\
\hline & & $\begin{array}{l}\text { Unweighted } \\
\text { (\%) }\end{array}$ & $\begin{array}{l}\text { Weighted } \\
(\%)\end{array}$ & $\begin{array}{l}\text { Unweighted } \\
\text { (\%) }\end{array}$ & $\begin{array}{l}\text { Weighted } \\
(\%)\end{array}$ & \\
\hline \multirow[t]{2}{*}{ Sex } & Male & 47.9 & 48.8 & 48.8 & 49.5 & 48.7 \\
\hline & Female & 52.1 & 51.2 & 51.2 & 50.5 & 51.3 \\
\hline \multirow[t]{8}{*}{ Age } & $18-24$ years & 7.9 & 10.0 & 5.5 & 9.1 & 10.2 \\
\hline & 25-34 years & 14.2 & 16.3 & 13.2 & 16.2 & 16.2 \\
\hline & $35-44$ years & 16.7 & 16.1 & 21.4 & 16.7 & 16.3 \\
\hline & $45-54$ years & 18.3 & 17.7 & 22.2 & 18.0 & 17.6 \\
\hline & 55-64 years & 17.7 & 16.6 & 18.7 & 16.7 & 16.3 \\
\hline & $65-74$ years & 13.7 & 12.1 & 12.2 & 12.7 & 12.4 \\
\hline & $75+$ years & 11.6 & 11.2 & 6.7 & 10.6 & 11.1 \\
\hline & Average (years) & 51.0 & 49.5 & 49.5 & 49.4 & 49.4 \\
\hline \multirow[t]{2}{*}{ Nationality } & Belgian & 83.9 & 88.6 & 85.8 & 90.3 & 87.8 \\
\hline & Non-Belgian & 16.1 & 11.4 & 14.2 & 9.7 & 12.2 \\
\hline \multirow[t]{2}{*}{ Born in Belgium } & Yes & 75.5 & 82.7 & 79.0 & 84.3 & 81.1 \\
\hline & No & 24.5 & 17.3 & 21.0 & 15.7 & 18.9 \\
\hline \multirow{2}{*}{$\begin{array}{l}\text { Born in country } \\
\text { with HCV } \\
\text { prevalence }>2 \%\end{array}$} & Yes & 5.4 & 4.0 & 4.8 & 3.3 & 3.2 \\
\hline & No & 94.6 & 96.0 & 95.2 & 96.7 & 96.8 \\
\hline \multirow[t]{3}{*}{ Region } & Flemish region & 37.3 & 56.0 & 45.4 & 59.2 & 58.2 \\
\hline & Brussels region & 25.9 & 10.4 & 23.9 & 10.5 & 10.2 \\
\hline & Walloon region & 36.9 & 33.6 & 30.8 & 30.3 & 31.6 \\
\hline \multirow[t]{4}{*}{ Urbanization } & $\begin{array}{l}\text { Big cities and dense } \\
\text { agglomerations }\end{array}$ & 46.4 & 38.5 & 46.5 & 38.3 & 38.7 \\
\hline & Suburban & 12.8 & 17.0 & 13.8 & 18.0 & 19.0 \\
\hline & Urbanized municipalities & 26.0 & 33.3 & 30.0 & 33.8 & 28.2 \\
\hline & Rural & 14.8 & 11.3 & 9.9 & 9.9 & 14.1 \\
\hline \multirow[t]{5}{*}{ Education } & $\begin{array}{l}\text { No diploma or primary } \\
\text { education }\end{array}$ & 7.6 & 6.4 & 3.9 & 3.8 & \\
\hline & Lower secondary & 13.2 & 13.0 & 9.9 & 11.6 & \\
\hline & Higher secondary & 29.6 & 32.3 & 30.0 & 31.2 & \\
\hline & Higher education & 47.7 & 47 & 54.6 & 51.9 & \\
\hline & No answer & 1.9 & 1.3 & 1.7 & 1.6 & \\
\hline \multirow[t]{2}{*}{ Ever cannabis } & Yes & 23.3 & 23.2 & 28.2 & 28.3 & \\
\hline & No & 76.7 & 76.8 & 71.8 & 71.7 & \\
\hline \multirow[t]{2}{*}{ Ever other drugs } & Yes & 8.8 & 9.4 & 8.2 & 9.3 & \\
\hline & No & 91.2 & 90.6 & 91.8 & 90.7 & \\
\hline Anti-HCV positive & & & & 0.1 & 0.02 & \\
\hline
\end{tabular}

Abbreviations: BELHES, Belgian Health Examination Survey; BHIS, Belgian Health Interview Survey. 
was found yielded an unweighted prevalence rate of $0.1 \%$ (95\% CI $0.00-0.29 \%)$ and an estimated weighted prevalence rate of $0.02 \%$ ( $95 \%$ CI $0.00-0.07 \%$ ).

Since we only had one positive anti-HCV case, extreme cautiousness is needed to interpret the seroprevalence estimate for the general population that was obtained in this study. However, the results might indicate that the prevalence in the Belgian population is much lower than in previous estimations (Beutels et al., 1997; Litzroth et al., 2019; Muyldermans et al., 2019). The reasons for this remain unclear. Indeed, the proportion of respondents from countries with a known high HCV prevalence was representative of the general population, with the exception of respondents from Egypt. Particularly respondents from countries such as the Democratic Republic of Congo $(n=13)$, Romania $(n=9)$, or Russia $(n=4)$ were well represented. Moreover, based on self-reported data from the questionnaire the positive case seemed atypical. The respondent never used any illicit substances which could have been injected and she was not born in a country where HCV is highly endemic. Other information about possible risk behavior was missing.

Several limitations can be mentioned. Indeed, although there is reason to believe that, as a result of many prevention and harm reduction initiatives, the prevalence of HCV has dropped over the past decade, the low prevalence figure could also be the result of selection bias. Firstly, previous analysis has already shown that participation in the BHIS is lower for people with lower education (Demarest et al., 2012). On top of that, in the current study respondents with higher education were oversampled in BELHES (51.9 compared to $47.0 \%$ for BHIS). As higher education is known to be a protective factor for HCV infection (Dalgard et al., 2003), this could have influenced our results.

Secondly, although for other known sociodemographic indicators the population structure of BELHES corresponds to the structure of the general population, some HCV risk factors were not registered in BELHES, such as history in prison, history of injecting drug use, or having tattoos. This could mean that certain hard-to-reach subpopulations such as former inmates or injecting drug users were underrepresented in BELHES. Also, the proportion of people who might be at risk for sexually transmitted infection of $\mathrm{HCV}$, for example, HIV-positive men who have sex with men, is unknown in the sample. Further prevalence studies on HCV through population surveys should guarantee the presence of these subpopulations.

Finally, if the HCV seroprevalence in the general population indeed is as low as suggested by the current study, a health examination survey might not be the most appropriate research design to correctly estimate a population-wide HCV estimate. Further research should balance cost-effectiveness with the possibility to reach out for potential subpopulations at risk, while guaranteeing stochastic variation.

Data Availability Statement. Aggregate data may be made available through a formal request to the first author, who will make any and all decisions regarding data sharing. No personally identifiable data will be provided.

Competing interests. The authors declare none.

Funding statement. This study received no specific grant from any funding agency in the public, commercial, or not-for-profit sectors.

Authorship Contributions. L.V.B. initiated the study and wrote the first draft of the manuscript. J.V.D.H. supervised the fieldwork. Both authors read and approved the manuscript.

Ethics Statement. The study was part of the BELHES project which was approved by the Ethical Committee of Ghent University. Participants signed an informed consent before the start of the interview.

\section{References}

Belgian Statistical Institute. (n.d.). Belgium. http://www.statbel.fgov.be

Beutels, M., Van Damme, P., Aelvoet, W., Desmyter, J., Dondeyne, F., Goilav, C., Mak, R., Muylle, L., Pierard, D., Stroobant, A., Van Loock, F., Waumans, P., \& Vranckx, R. (1997). Prevalence of hepatitis A, B and C in the Flemish population. European Journal of Epidemiology, 13, 275-280. https://doi.org/10.1023/A:1007393405966

Dalgard, O., Jeansson, S., Skaug, K., Raknerud, N., \& Bell, H. (2003). Hepatitis C in the general adult population of Oslo: Prevalence and clinical spectrum. Scandinavian Journal of Gastroenterology, 38, 864-870. 
Demarest, S., Van der Heyden, J., Charafeddine, R., Drieskens, S., Gisle, L., \& Tafforeau, J. (2013). Methodological basics and evolution of the Belgian health interview survey 1997-2008. Archives of Public Health, 71, 24. https://doi.org/10.1186/ 0778-7367-71-24

Demarest, S., Van der Heyden, J., Charafeddine, R., Tafforeau, J., Oyen, H., \& Van Hal, G. (2012). Socio-economic differences in participation of households in a Belgian national health survey. European Journal of Public Health, 23, 981-985. https://doi.org/10.1093/eurpub/cks158

European Centre for Disease Prevention and Control. (2020). Technical protocol for hepatitis $C$ prevalence surveys in the general population: SPHERE C project. Publications Office. https://data.europa.eu/doi/10.2900/30190

Gower, E., Estes, C., Blach, S., Razavi-Shearer, K., \& Razavi, H. (2014). Global epidemiology and genotype distribution of the hepatitis C virus infection. Journal of Hepatology, 61, S45-S57. https://doi.org/10.1016/j.jhep.2014.07.027

Hofstraat, S. H. I., Falla, A. M., Duffell, E. F., Hahné, S. J. M., Amato-Gauci, A. J., Veldhuijzen, I. K., \& Tavoschi, L. (2017). Current prevalence of chronic hepatitis $\mathrm{B}$ and $\mathrm{C}$ virus infection in the general population, blood donors and pregnant women in the EU/EEA: A systematic review. Epidemiology \& Infection, 145, 2873-2885. https://doi.org/10.1017/ S0950268817001947

Litzroth, A., Suin, V., Wyndham-Thomas, C., Quoilin, S., Muyldermans, G., Vanwolleghem, T., Kabamba-Mukadi, B., Verburgh, V., Jacques, M., Van Gucht, S., \& Hutse, V. (2019). Low hepatitis C prevalence in Belgium: Implications for treatment reimbursement and scale up. BMC Public Health, 19, 39. https://doi.org/10.1186/s12889-018-6347-Z

Muyldermans, G., Bielen, R., Botterman, R., Bourgeois, S., Colle, I., Deressa, B., Devolder, G., Horsmans, Y., Hutse, V., Lanthier, N., Lasser, L., Platteau, S., Robaeys, G., Suin, V., Verhelst, X., Vlierberghe, H., \& Baelen, L. (2019). Hepatitis C virus $(\mathrm{HCV})$ prevalence estimation in the adult general population in Belgium: A meta-analysis. Acta Gastro-Enterologica Belgica, 82, 479-485.

Nguyen, D., Hautekiet, P., Berete, F., Braekman, E., Charafeddine, R., Demarest, S., Drieskens, S., Gisle, L., Hermans, L., Tafforeau, J., \& Van der Heyden, J. (2020). The Belgian health examination survey: Objectives, design and methods. Archives of Public Health, 78, 50. https://doi.org/10.1186/s13690-020-00428-9

Van Baelen, L., Plettinckx, E., Antoine, J., \& Gremeaux, L. (2020). Prevalence of HCV among people who inject drugs in Brussels - A respondent-driven sampling survey. Harm Reduction Journal, 17, 11. https://doi.org/10.1186/s12954-02000358-3

World Health Organization. (2016). Combating hepatitis B and C to reach elimination by 2030.

Cite this article: Van Baelen L, Van der Heyden J (2021). Hepatitis C virus prevalence in Belgium Experimental Results, 2, e29, 1-8. https://doi.org/10.1017/exp.2021.20 


\section{Peer Reviews}

\section{Reviewing editor: Prof. Martin Michaelis}

University of Kent, School of Biosciences, Canterbury, United Kingdom of Great Britain and Northern Ireland, CT2 7NJ

This article has been accepted because it is deemed to be scientifically sound, has the correct controls, has appropriate methodology and is statistically valid, and has been sent for additional statistical evaluation and met required revisions.

\section{doi:10.1017/exp.2021.20.pr1}

\section{Review 1: Hepatitis C virus prevalence in Belgium}

Reviewer: Dr. Sylvester Lokpo iD

Date of review: 02 September 2021

(C) The Author(s), 2021. Published by Cambridge University Press. This is an Open Access article, distributed under the terms of the Creative Commons Attribution licence (http://creativecommons.org/licenses/by/4.0), which permits unrestricted re-use, distribution and reproduction, provided the original article is properly cited.

Conflict of interest statement. I confirm that no competing interest exists by entering these responses

\section{Comment}

Comments to the Author: Acronyms at first mention in the text were not written in full for e.g those found in lines 38 and 76. Kindly fix them.

While authors provided reagent details for anti-HCV testing, they failed to do the same for PCR testing. Such details are important for readership and reproducibility.

The critical study outcome which is the seroprevalence of HCV was not presented in Table 1 or any other table or figure, hence, it is difficult to link the result discussed to those presented in Table 1.

Readership will benefit immensely if authors provide statements on the potential limitations of their study, as this was not stated.

\section{Score Card}

Presentation

Does the paper cite relevant and related articles appropriately? (30\%)

Context

Does the abstract correctly embody the content of the article? (25\%)

Does the introduction give appropriate context? (25\%) 
Are the limitations of the experiment as well as the contributions of the experiment clearly outlined? (20\%) 


\section{Review 2: Hepatitis C virus prevalence in Belgium}

Reviewer: Thomas Seyler

Date of review: 14 July 2021

(c) The Author(s), 2021. Published by Cambridge University Press. This is an Open Access article, distributed under the terms of the Creative Commons Attribution licence (http://creativecommons.org/licenses/by/4.0), which permits unrestricted re-use, distribution and reproduction, provided the original article is properly cited.

Conflict of interest statement. Reviewer declares none

\section{Comment}

Comments to the Author: The study is very useful in the framework of the elimination effort. However it lacks a discussion section where the authors would interpret the results in the light of past surveys, other European surveys, and discuss in more details the limitations of population surveys that might not reach high-prevalence key populations.

\section{Score Card}

Presentation

Does the paper cite relevant and related articles appropriately? (30\%)

Context

Does the abstract correctly embody the content of the article? (25\%)

Does the introduction give appropriate context? (25\%)

Is the objective of the experiment clearly defined? (25\%)

Analysis

Are the limitations of the experiment as well as the contributions of the experiment clearly outlined? $(20 \%)$ 